\title{
CAPTAIN JACK WHITE: ULSTER PROPHET OF DISSENT
}

\begin{abstract}
This article deals with the life and philosophy of Captain Jack White (1879-1946). He was from a family of Ulster Presbyterians, a son of a Field Marshal and member of the upper echelons of British society. He abandoned his privileged background to become a founder of the socialist militia, the Irish Citizen Army, military advisor to the nationalist Irish Volunteers, comrade to the revolutionary Countess Markievicz, an anarchist and participant in the Spanish Civil War. His career transcended the political, social and religious divisions that shaped Irish and British politics in the $20^{\text {th }}$ century.

His remarkable life included military honours in the Boer War, a mystical experience on the Rock of Gibraltar, correspondence with Leo Tolstoy and participation in a commune in Edwardian England. He was at home in Bohemian artistic circles and once punched D.H. Lawrence (fictionalised in Lawrence's novel Aaron's Rod) in an argument over love. Towards the end of his life he corresponded with the writer and philosopher, John Cowper Powys.

In Ireland his questing spirit alienated many former allies and he became a marginal political figure. After his death his political legacy was relegated to a footnote until recent times when he has emerged as a striking figure in Irish history, a distinguished inheritor of the Ulster tradition of scepticism and dissent. The article will trace the relevance of his libertarian life and outlook to the current Irish political situation in the shadow of Brexit.
\end{abstract}

Keywords: Ulster, Irish Volunteers, dissent, Home Rule, nationalism

\section{"Fighting for spiritual breath..."}

In January 1927 the writer, Liam O'Flaherty, was invited to an extraordinary gathering in a ruined mansion on a Dublin mountain. The organizer had invited "country people from the neighbourhood and about a hundred friends from town. There were lousy tramps and very important government officials, intellectuals, bourgeoisie, peasants, servants etc., all together." A tall man of military bearing in formal evening clothes appeared and made an extraordinary speech "the counterpart of which you

1 L. O'Flaherty, The Letters of Liam O'Flaherty, Dublin: Wolfhound Press, 1996, p. 173. 
might find in Dostoievsky's Possessed at the governor's ball. The wind howled, there was snow and motor cars broke down. I never saw anything like it."2 The speaker was Captain James (Jack) White, known to the Irish public as a founder of the socialist militia, the Irish Citizen Army and organizer of the nationalist Irish Volunteers.

O'Flaherty did not record the speech but the scene might have come from one of his novels; Jack White was a larger than life character, tormented by spiritual insight which he was unable to reconcile with any existing religion or political philosophy. A generous and humorous man, he was often in dispute with foes and comrades in a life-long struggle to formulate a vision of a just and equal society. He was hostile to the dominating influence of the Catholic Church, but found Catholic women attractive and married two in attempts to reconcile opposites. He had many of the qualities of a saint or Messiah, but in the turbulent early $20^{\text {th }}$ century could not find a permanent role in any organization.

There are individuals whose energies are so unusual that they do not fit into categories and are neglected by historians. Jack White had the temperament of a preacher inherited from his Ulster Protestant ancestors allied to the desire to overturn oppressive authority. He was a prophet without followers whose impact on contemporary events was blunted by his individualism and impatience with the tunnel vision of people in organizations. He mixed in bohemian circles and is featured in a number of novels, notably in D.H. Lawrence's Aaron's Rod, where the author fictionalised an encounter in which White punched him in the stomach.

Captain James White is remembered in Ireland for his role in the formation of the Irish Citizen Army and the Irish Volunteers in the crucial years of 1914-1915, and then he drops out of the narrative. In fact he did not disappear but continued attempts to influence events from the margins. He was active in revolutionary politics in England and Spain in the 1920s and '30s, but became a footnote in history. The Irish State's attempt to commemorate him during the centenary celebrations in 2013 turned to farce when a postage stamp bearing his name was found to have the wrong image. The stamp was withdrawn, but the episode was indicative of the ignorance surrounding the man in modern times.

$\mathrm{He}$ is buried in the family vault in the village of Broughshane, County Antrim, among his ancestors who resided in the nearby house, White Hall, since the $17^{\text {th }}$ century. Given the predominantly Unionist politics of the area it is hardly surprising that there is no plaque or memorial to his role in Irish history.

Captain James Robert (Jack) White, DSO (Distinguished Service Order) was the son of Field Marshall George White, the "Hero of Ladysmith" (reputed the most decorated soldier in the British Army) and Amelia Mary White (nee Baly). For centuries the family home was at White Hall outside the village of Broughshane, County Antrim, near the slopes of Slemish, an extinct volcano where, according to legend, St. Patrick herded sheep and swine. Unlike the majority of Protestant colonists, who

Ibidem, p. 174. 
came to Ireland from Scotland, the White ancestors originated in Yorkshire. They were landowners who fought for King Charles I in the English Civil War (16421651). As a supporter of the losing side Fulke Whyte lost his lands and sought refuge in Ulster where he "maintained himself and family by teaching a classical school, being a clergyman of the Presbyterian faith." 3

The White family prospered in Broughshane as preachers and landlords. According to local doctor, Tony Redmond, they were renowned for being honest and fair to tenants when the majority of landlords were detested for extracting as much rent as possible. The family were admired for a spirit of independence and strength of character that verged on eccentricity. The expansion of the British Empire created many opportunities for sons of the landed gentry and Jack's father took up a career in the military. Like the majority of their class they regarded themselves as English in Ireland and had family connections in England where Jack was born at Richmond, Surrey on 22 May, 1879. His father, Field Marshall Sir George Stuart White (1835-1912), achieved military glory when he single-handedly charged a group of Afghan rebels and won the Victoria Cross.

The young Jack was sent to Winchester public school where he was high-spirited and rebellious and often flogged by headmasters. He wrote in his autobiography: "I suffered all my early life, until I broke away from mechanical custom, from what can only be termed paroxysms of boredom... I fought, as it were, for spiritual breath, for there is deadly enmity between my spirit and all mechanical forms." 4

He won a cadetship to the Royal Military Academy at Sandhurst. Despite brushes with authority he persevered and received a commission. He was mixing with the aristocracy and received an invitation to dine with a friend. When he could not find his top hat he searched for a substitute. "So I went in an evening tail-coat and a bowler hat; in those days, and to such a company, an outrage. I was never secure against this latent anarchist. He kept cropping up until he got me in the end." 5

In January 1899 he was commissioned into the $1^{\text {st }}$ Gordon Highlanders and shipped to South Africa to fight in the Boer War. Despite his military background he was appalled at the waste of war-the stupidity and inefficiency of the officer class and their disregard for the lives of the soldiers. His experiences turned him against the British Empire, but the military training and bearing he acquired were useful assets in the years to come. He fought at the Battle of Doornkop on 27 May 1900, an area now covered by a suburb of Soweto. After leading his men in a successful advance he discovered the Boers had abandoned their positions. There was only one terrified teenage fighter who was easily taken prisoner. "Then arrived an officer, my superior in rank... "'Shoot him, shoot him,' yelled the officer. A wave of disgust swamped my sense of discipline. 'If you shoot him,' said I, pointing my carbine at

L. Keohane, Captain Jack White: Imperialism, Anarchism and the Irish Citizen Army, Kildare: Merrion Press, 2014, p. 11.

Captain J. White, Misfit: An Autobiography, London: Jonathan Cape, 1930, p. 16.

Ibidem, p. 34. 
him, 'I'll shoot you,' and he passed on. He is now a General, that officer, and I am a Bolshevik, or reported as such."6

Amazingly, there were no repercussions, perhaps because of his father's rank. White later won a DSO (Distinguished Service Order) for bravery when he escaped from captivity with the Boers. Sir George became Governor of Gibraltar in 1900 with Jack as aide-de-camp after the Boer War ended in 1902. Before long he met and fell in love with Dollie Mosley, a beautiful half-Spanish Catholic woman, a match both families tried to prevent. His official duties consisted of sending invitations to parties in honour of visiting dignitaries such as King Edward VII and Kaiser Wilhelm. Edward, the playboy king, was in the habit of seducing beautiful women he selected at private dinner parties. White was given a list of invitees on which Dollie's name was included. "...half of me was proud of the notice of Dollie's beauty; the other half of me said, "This Pimping for princes might have its limitations."'7

\section{"I cursed Tolstoy and died."}

White would remember Gibraltar all his life because of a life-changing experience in 1904. He was walking on the Rock trying to reconcile the opposing stances of the Mosley and White families to his romance with Dollie. The outbreak of war between Russia and Japan was bearing on his mind. "I lay down half-way up the Rock and fell into an exhausted doze for some ten minutes. When I woke, the conflict was resolved... This took the form of the most pleasurable sensation in the middle of my chest, as if I had just drunk a strong liqueur." 8

The term "liqueur sensation" appears a weak phrase to describe a life-changing experience of elevated consciousness. It appears to have traits in common with the elated state experienced by poets and mystics and was the subject of the book, Cosmic Consciousness, by the Canadian psychiatrist, Richard M. Bucke, published in 1901. White went on: "The liqueur-sensation played the biggest part in driving me out of the army, to Canada, into various prisons and awkward predicaments beyond number... this irresistible if at first unintelligible driving force... As I read the telegrams about the Russo-Japanese War and felt the swelling ecstasy within me, this idea was born: 'you belong to a whole... in organic connection with universal worldwide forces which this Russo-Japanese War is beginning to set in motion."

There is much more in his autobiography about the liqueur sensation and his efforts to understand it. As the decade went on he found military discipline increasingly difficult to bear, but had no idea what path to follow. He still thought of himself as a loyal British subject, but the effect of the liqueur sensation was to question his

Ibidem, p. 45.

Ibidem, p. 70.

Ibidem, p. 64.

Ibidem, pp. 65-66. 
previously accepted values. "Napoleon said of the English they never know when they are beaten. The fight I put up now was purely Irish in quality, though at this time I hardly knew of himself as an Irishman... I fought for the sake of fighting, without hope of success." 10

He married Dollie in April 1907 and resigned from the British Army in the following year. The following years saw him embark on a spiritual quest to understand his own self and the nature of humanity. He studied the writings of H.G. Wells and corresponded with him. Leo Tolstoy became his teacher as he attempted to follow the master's principles on vegetarianism and celibacy. He once travelled to Bohemia on a diet of dates and biscuits: "I got the most appalling pain in my stomach I ever remember." It was only relieved by drinking brandy; "Thank God I had kept clear of teetotalism." 11 While teaching English at a language school in the city of Tabor, a Czech professor requested that he read Oscar Wilde's The Picture of Dorian Gray to him in English. As White found Czech too difficult to explain the text, he insisted on using German, which the Czechs detested, and was dismissed.

The quest for enlightenment involved living for a while as a tramp, a term milking cows in England and Gulag-like conditions in a Canadian logging camp. He moved on to clearing scrubland, but found he was unfit for the job. "I was not a peasant. I was not a farm labourer. In respect to that particular incarnation I cursed Tolstoy and died." 12 During these years he tried to impose a rigid control of mind over body but was forced to acknowledge that the latter had its needs. He sent a letter to the master with details of his struggle to practise his philosophy. Tolstoy wrote back to assure him they were kindred spirits.

His autobiography describes years of attempting to reconcile his Protestant distrust of organisations and philosophies with a belief system that could encompass insights derived from the "liqueur sensation" experience. A Nietzschean drive and ambition to surmount obstacles caused intense frustration in finding a role in society. He had a sense of being chosen for a high purpose, but unlike most Messiahs, did not look for disciples. He revelled in challenges that revealed his strengths and weaknesses, at the same time searching for a cause into which he could pour his restless energy; he wanted to be connected to the world.

"Destiny ceases to be blind," he wrote. "The idea behind it emerges. It emerges to persons and even to places." ${ }^{13} \mathrm{He}$ and Dollie joined the Whitewater commune in England run by the translator of Tolstoy, Aylmer Maude, but found the regime too strict. They left with the more amorously inclined to a breakaway commune, Whiteways, in the Cotswolds. At this stage White reckoned he had outgrown his master

\footnotetext{
$10 \quad$ Ibidem, p. 90.

$11 \quad$ Ibidem, p. 108.

12 Ibidem, p. 128.

13 Ibidem, p. 117.
} 
and mentor. "I felt I had bitten deeper than Tolstoy, because I had tried him out as he never tried himself." 14

In 1913 he found a cause in the last place he expected - the ancestral homeland of Ireland. The Liberal Party, then in power in Britain, proposed a limited form of Home Rule government in Ireland. The Conservative Party perceived the plan as beginning the dismemberment of the British Empire and encouraged Loyalists in Ireland (mainly Protestants, but not exclusively) to take up arms in opposition to the Government. White travelled to Belfast where he spoke at a meeting of Protestants for Home Rule alongside George Bernard Shaw and Sir Arthur Conan Doyle. He had decided the Irish problem was really the "sex-problem" on a vast scale with masculine authoritarian Protestantism attempting to suppress the feminine principle of Irish Catholicism. He felt he was the ideal person to reconcile the two forces.

When he came to Dublin his socialist instincts were aroused at the brutality of the police towards strikers and protestors. He offered his military skills to the trade union organiser and socialist agitator, James Connolly, to set up the workers militia, the Irish Citizen Army. One can sense his delight at being back on the parade ground, making soldiers out of citizens, but this time for a cause he believed in. The treasurer to the Citizen Army was the colourful revolutionary, Constance de Markievicz, wife of a Polish painter, writer and theatre director, who became a close ally and friend. She had a strong sense of the theatrical, aware that uniforms were symbolic as much as practical, and supported White's proposal for a distinct image for the ICA. White's initial drilling and training prepared the Citizen Army for their role in the 1916 Easter Rising.

White was dissatisfied with the slow growth of the Citizen Army and claimed he could have transformed Ireland with 20,000 men. The Citizen Army never grew beyond a few hundred. In 1914 he resigned and offered his services to the nationalist militia formed to defend Home Rule, the Irish Volunteers. This was his high-water mark as a revolutionary leader when he engaged in training a force that reached 168,000 at its peak. When the Great War began in August 1914 he proposed that the British Government employ the Irish Volunteers as an Irish Home Guard. The result was the opposite of expectations: "I was profoundly misunderstood. I was taken to be recruiting for Britain, whereas I was trying to use Britain to put Ireland into a positon to enforce her own claims." ${ }^{15}$ His daring proposal met with opposition and he left the Volunteers. While his trenchant and individualist views usually brought conflict with the leadership of organizations, he maintained his friendships with Connolly and de Markievicz.

$14 \quad$ Ibidem, p. 157.

$15 \quad$ Ibidem, p. 319. 


\section{"...a bird with one wing"}

He detested the carnage of the Great War, but could not remain inactive. In 1915 he converted his Ford two-seater car into an ambulance and drove with Dollie to the front in Belgium. "For a time I fetched carloads of blasted humanity off the "wounded' trains and distributed them around the Dunkirk hospitals. I saw enough to intensify my instinctive loathing of the whole filthy mechanical slaughter-yes, and my contempt for the mentality that could accept it as all in the day's work. I wanted to get outside, above it all, get behind the roots of the filthy thing in the human mind and soul."'16

He was regarded with suspicion by the British Red Cross because of his support for the Irish Volunteers who were sympathetic to Germany. He and Dollie retired to Paris and to a hotel off the Rue Bonaparte where they decided they had enough of the war. Dollie went to her mother in Gibraltar and they appear to have divorced some time afterwards. White mingled with the artistic set around Maud Gonne, Yeats's beloved, in her Passy apartment and became involved in a ménage à trois with an American artist and his wife. He discovered a new creed to his ever-growing listfeminism. The Great War, he decided, was caused by frustration due to an excess of love: "I saw humanity as a bird with one wing, attacking itself as a crippled bird is attacked by the flock. Women are not yet functioning as free individuals. The War would ultimately cure the root evil which had caused it by completing the freeing of women, which had begun; but that completion would pass far beyond the political and economic emancipation." 17

He was watching events in Ireland and produced a manifesto for the pacifist paper, the 'Irish Citizen', in November 1915. The essay gave an insight into his thinking at a time of global convulsion, but what would readers make of remarks like: "The only true statesman is the seer; perhaps that is why England has none and Ireland has too many."? ${ }^{18}$ The essay was visionary, a call to spiritual awakening leading to a society of equals based on justice and freedom. It looked back to the great rebellion of 1798, led in part by Ulster Protestants and inspired by the ideals of the French Revolution. "France poured the aspirations of her sons into a great progressive desire, so far spiritual as to have left to this day a unity of self-governing individuals, a passionate Nationalism so intense as to triumph over even its own sad cynicism."19

He made a ringing appeal for spiritual renewal, linking his argument to the topical issue of whether conscription into the British armed forces would be imposed on Ireland: "Is Ireland destined to be one of the foundations, if not the corner-stone, of the new order? Pre-eminent in Europe, she has retained her spiritual outlook... Can

\footnotetext{
$16 \quad$ Ibidem, p. 341.

17 Ibidem, p. 344.

18 Captain White, "Ireland's Hour," The Irish Citizen, 27.11.1915.

19 Captain White, "Ireland's Hour (part 2)", The Irish Citizen, 4.12.1915.
} 
she link her suffering past to a triumphant present? ... I believe that her hour of trial is at hand. Will she see that the true spirituality is the vindication and enthronement of the Woman ... hallowed by refusal to resist evil by violence ... If Conscription comes, will she take her stand in calm assurance on the ground of her National rights, rendered invincible by alliance with eternal truth?"20

However eloquent the rhetoric, the appeal was issued in a vacuum - he was a lone voice on the sidelines. The Rising of Easter 1916 set relations between Ireland and Britain on a course of conflict. White took no part in the Rising and has been excluded from the narrative of Irish history as a result. In the aftermath he tried to organise a miners strike in Wales to prevent the execution of James Connolly. His intention was to cut off the coal supply to the British Fleet; it is doubtful if such a quixotic attempt could have succeeded. On the day of his arrest Connolly was strapped to a chair and shot by firing squad in Dublin. White was sentenced to three months in Swansea Jail. The lenient sentence can only be attributed to his military record as his treasonable actions could have resulted in the death penalty. He was transferred to Pentonville Prison and was kept in a cell near Roger Casement on the morning of his execution. In December 1916 he visited Constance de Markievicz, then in Aylesbury Women's Prison for her role in the Rising, and lobbied officials to improve her conditions. When she was released in June 1917 White was one of the first friends she met in London. He arrived in top hat and spats and celebrated her freedom with tea and strawberries on the terrace of the Houses of Parliament.

He was now mixing in London literary circles; on one memorable occasion he visited D.H. Lawrence and his wife, Frieda, in their rural cottage. A love triangle began to unfold as Frida expressed annoyance with Lawrence by flirting with White. Things came to a head during an intense argument about love when White gave Lawrence a punch in the stomach. Lawrence used the incident in his roman a clef, Aaron's Rod (1922). In a chapter entitled, A Punch in the Wind, White appears as Jim Bricknell, an opinionated ex-army officer, described as "a sort of socialist and a redhot revolutionary of a very ineffectual sort." ${ }^{21}$

Bricknell arrives at the Hampshire cottage of writer Rawdon Lilly (Lawrence) and proceeds to stuff himself with bread. Lawrence gleefully reproduces White's manner of speech: "I only live when I can fall in love. Otherwise I'm dying by inches... I used to get the most grand feelings - like a great rush of force, or light - a great rush — right here, as I've said, at the solar plexus..."22 Lawrence mercilessly satirized his friends in the novel, making it hard to distinguish fiction from fact, but scholars accept that a violent row took place. Many of Lawrence's friends found themselves caricatured in his novels and some undoubtedly would have wished, like White, to have thrown the first punch. Another acquaintance satirized in Aaron's Rod was Hilda

20 Ibidem.

21 D.H. Lawrence, Aaron's Rod, Middlesex: Penguin Books, 1968, p. 91.

22 Ibidem, p. 103. 
Doolittle (H.D.) who also wrote a roman-a-clef, Bid Me to Live (written 1927, published 1960), in which White again appeared as Captain Ned Trent, an Irish drifter among the aimless artists and intellectuals during the Great War.

Ineffectual he may have been, but White was constantly attempting to influence events. His pamphlet, The Significance of Sinn Fein - Psychological, Political and Economic, was published in Dublin soon after the party's electoral victory in December 1918. Sinn Fein refused to take their seats in Westminster and set up an Irish parliament in Dublin, the First Dail, in which Constance was Minister for Labour. The pamphlet was another attempt by White to synthesize his theories with the rapidly developing political situation. He argued that there were two conflicts in Ireland-race and class. The racial struggle was the effort to gain independence while the labour struggle represented the urge for economic justice. Both had to be pursued to achieve genuine independence. Despite their inferior numbers he lauded the role of Connolly and the "Labour Citizen Army" as the "driving force" of the 1916 Rising.

He reserved his sharpest words for the leaders of Protestant Ulster: "The ascendancy caste in Ulster are the fortified outposts of England's rule in Ireland ... Ulster is the profiteer's paradise... Her workers have not yet realised that they have dammed themselves off from the twentieth century by their concentration on damning the Pope..." 23 It was a critique that predicted much of twentieth century history in the province.

White moved between Dublin, London and Belfast in the 1920s and spent prison terms in each jurisdiction. He was involved with left-wing groups, but it appears to have been a lost decade. He knew T.E. Lawrence, of Arabia fame, who combined thought with action in a manner that appealed to intellectuals as a fully integrated man. The relationship belongs to literary legend, but according to the writer John Cowper Powys, White “....got that Greatest Prig and most Conceited Prig of all our writers and of all our men of action, Lawrence of Arabia to 'midwife' his first book called Misfit..."24 He still had many friends and contacts in Dublin. Liam O'Flaherty declared his Wicklow home off-limits to visitors, except for interesting people like Captain White and Constance de Markievicz. She may have come closest to the soul-mate he sought in his marriages - he was always "Jimmy" to her. Both were constantly questing after truth, deeply spiritual, drawn towards creative artists, but absorbed with politics. They did not fit inside the limited categories which tidy minds were inclined to impose. He lost an ally when, a few weeks after being elected to the Free State Dail, she suddenly died in 1927. According to White's son, the late Derrick White, his mother thought the relationship with Constance was "too intimate" 25 but there is no evidence of a physical affair.

23 J.R. White, The Significance of Sinn Fein - Psychological, Political and Economic, Dublin: Martin Lester, p. 19.

24 L. Keohane, Captain Jack White ..., p. 186.

25 Derrick White, unpublished review of Misfit, given to the author by Dr Tony Redmond. 


\section{"...two lines in my life..."}

He may have tired of being caricatured in other people's books and produced his own. Misfit, an Autobiography by Captain J.R. White D.S.O. was published by Jonathan Cape in 1930; the book deals with his spiritual quest and political career up to 1916. It is at times erratic, obscure, funny, self-justifying and self-lacerating and is one of the most unusual books produced by any political figure. At times he appears to attempt to baffle and confuse the reader. He declares in the foreword: "I have followed two lines in my life, roughly speaking, the lines of Christ and Lenin." Comparisons could be made with his contemporary Nikos Kazantzakis (1883-1957) who followed a similar path, but was able to explore his conflicts in literature.

The 1930s saw the arrival of a new cause - support for the Anarchists in the Spanish Civil War. He travelled to Spain and reprised his Great War role by providing an ambulance team. Back in England he spoke at meetings in support of the Spanish anarchists. At one of these he shared a platform with the veteran anarchist, Emma Goldman, who was a correspondent with the philosopher-novelist, John Cowper Powys, who had moved from the United States to live in Corwen, a remote village in North Wales. Powys was the author of novels dealing with the influence of psychic forces in daily life, most notably Wolf Solent (1929), A Glastonbury Romance (1932) and Weymouth Sands (1934). He was also the author of philosophy books and essays-The Meaning of Culture (1929), In Defence of Sensuality (1930), A Philosophy of Solitude (1933) etc. which preached a doctrine of personal responsibility, an intense appreciation of nature and avoidance of dogma that White found appealing. White found a kindred spirit in Powys and began a correspondence which lasted until his death.

He married Noreen Shanahan in London in 1938, his second marriage to a Catholic, which led to many rows over religion. They returned to the ancestral home at White Hall where they brought up three sons, Tony, Derrick and Alan. White was now writing a sequel to Misfit, called in some quarters, Misfit 2, which continued his life story with more exegesis of his philosophy. He requested a critique of the manuscript from his new mentor and Powys responded in glowing terms, comparing him to Dostoevsky and Gogol. Powys wrote in his diary in November 1941 that White "is now getting me to 'midwife' his second book containing bolder prophetic utterances than any Lawrence whether of Derbyshire or of Arabia has ever dared to publish... I gave up my walk yesterday afternoon and only posted my Letter to Mr White about his book of Revelation." 26

After White's death the manuscript disappeared and was presumed destroyed, although his biographer believes it may be wrongly catalogued in the British National Archives. White's niece, Patricia Napier, spent time in a tuberculosis sanatorium in Wales during the war where Powys visited and wrote to her about her uncle's book:

26 L. Keohane, Captain James White..., p. 241. (All quotations by John Cowper Powys were transcribed from his diaries and journals by his biographer, Dr Morine Krissdottir.) 
"I've never read a more honest book, for on my life, I don't believe there is a more honest book... I mean a book in which a man or woman talks of themselves and tries to explain themselves! Well I envy you the thrill—and everyone else who gets it later in print..."27

World War Two saw White confined to Antrim, but White Hall was no Yasnaya Polyana with a circle of disciples. He offered his military experience to the military authorities in the struggle against Fascism, but was refused. Income from the estate had been frittered away and he depended on growing and selling vegetables. In those bleak years the correspondence with John Cowper Powys was an important link to an understanding mind. We can only speculate about the content of the letters between them, but the language was uninhibited. Powys wrote in his diary of 17 November 1941: "I confined myself to posting my letter to old 'White of White' that War-SexMacro-Micro of White-hall (County Antrim) who either 'kicked' (or wanted to kick) 'the ARSE' of Lawrence of 'Sons and Lovers' and I expect if he ever gets displeased with me will 'Kick my arse' too!"'28 Powys noted on 21 March 1942 that he had received "a letter from White of White in anger accusing me of being lazy, 'superior'; false and smug; like all the English! And saying he was angry with me \& felt contempt for my character \& would like to kick me in the BALLS." ${ }^{29}$

Despite the occasional violent language Powys relished the outpourings of the volatile Irishman, describing him as one of his two most favoured correspondents. He noted in his diary of 10 January 1945 receipt of a letter from White saying he had "a malignant growth in his prostrate and is being cured by pills made of female hormones." ${ }^{30} \mathrm{He}$ further noted on 19 March: "White of White has cancer of the Prostate Gland. White of White believes that his revelation from God will cure it." ${ }^{31}$ According to Leo Keohane, White had strength enough to announce his candidacy in the British general election of August 1945. As ever he went against the established order by standing as a Socialist Republican in a Loyalist area. He hired the Orange Hall in Broughshane and made a speech denouncing all politicians and institutions including Hitler, Churchill, the Pope and the Orange Order. He was now seriously ill and did not proceed with the candidacy.

On 22 December 1945 Powys noted "the mental and physical pain and fear endured by old White of White." 32 Neither spiritual revelation nor bouts of solitary drinking could stop the cancer. Tony Redmond, doctor in Broughshane for many years, heard anecdotes of White passing through the village on horseback late at night to distant drinking dens. Powys wrote on 29 December about receiving a: "Tragic letter from White of White saying that half a bottle of whiskey made his Cancer of

\footnotetext{
27 J.C. Powys to Patricia Napier, private letter, $\mathrm{n} / \mathrm{d}$.

28 L. Keohane, Captain Jack White..., p. 241.

$29 \quad$ Ibidem, p. 186.

$30 \quad$ Ibidem, p. 241.

31 Ibidem.

32 Ibidem.
} 
the Prostrate worse and he was due for that operation where you 'excrete' through tubes on your front bowels. He asks my advice about suicide...on principle I defend Suicide, but I would be too cowardly to kill myself." ${ }^{33}$

White died in a Belfast nursing home on Sunday, 3 February 1946; Powys recorded the death in his entry of 7-9 February: "DEATH OF White of White may he rise to Immortality and Intense Happiness. $\mathrm{O}$ it is such a relief to me that he is out of it..."34

The connection with Powys was more enduring than many of White's previous friendships. He found someone tolerant and non-judgemental enough to try and understand behaviour and attitudes most people dismissed as deranged. We can only hope that White found answers that satisfied him in the correspondence. He wrote in Misfit: "I am what I call an introvert, I believe. I look inwards to the roots of things; that is, away from environment, for a start anyhow, to principles; away from effects to causes. So I'm apt to find that things, looking solid enough to the outer eye, are to the inner eye the dying effects of a dead cause." 35

His quest led him through nearly every belief system except Catholicism and Fascism until he settled on a term popularised by Tolstoy and called himself a Christian Anarchist. Many considered him mentally unbalanced, a madman and a self-centred individualist. The fair-minded conceded he was sincere, idealistic, unwilling to compromise his beliefs and a champion of the oppressed. His philosophical journey was not in any way typical of his Presbyterian forebears or of Ulster Protestants in general, but his background gave him a stubborn integrity that made him sceptical of all creeds and ideologies. According to his son, Derrick: "His politics were very much of the old 1798 United Irishmen school of Wolf Tone and other great Irish Protestants." ${ }^{36}$

While he is respected for his limited historical contribution among Irish republicans, White's individualism made him a marginal figure in Irish history. He can easily be viewed as a man out of step with the times or as someone ahead of conventional beliefs. The zeitgeist in the early twenty-first century is sceptical of ideologies and more receptive to those who encourage people to think for themselves. The life of Captain James White is of interest for the perspectives it reveals on the intersection between spiritual belief and political activism. His Presbyterian Ulster heritage produced in him an integrity that is part of the complex weave of Irish identity. He is an inspiration to the misfits and seekers after truth, for the persistent dreamers of a better world.

\footnotetext{
Ibidem, p. 242.

Ibidem.

Captain J. White, Misfit..., p. 99.

D. White, review of Misfit.
} 


\section{References}

Doherty, G., Keogh, D. (eds.), 1916: The Long Revolution, Cork: Mercier Press, 2007.

Doolittle, H.D., Bid Me to Live, London: Virago, 1984.

Durand, M., The Life of Sir George White, 2 vols., London: Wm. Blackwood \& Sons, 1915.

Fox, R.M., The History of the Irish Citizen Army, Dublin: James Duffy, 1944.

Goodway, D., Anarchist Seeds Beneath the Snow: Left-Libertarian Thought from William Morris to Colin Ward, Oakland, CA: PM Press, 2012.

Keohane, L., Captain Jack White: Imperialism, Anarchism and the Irish Citizen Army, Kildare: Merrion Press, 2014.

Krissdottir, M., Descents of Memory: The Life of John Cowper Powys, New York \& London: Overlook Press, 2007.

Lawrence, D.H., Aaron's Rod, Middlesex: Penguin Books, 1968.

Lee, J., Ireland 1912-1985, Cambridge: Cambridge University Press, 1989.

O'Flaherty, L., The Letters of Liam O'Flaherty, Dublin: Wolfhound Press, 1996.

Quigley, P., “John Cowper Powys \& the Misfit Messiah," La Lettre Powysienne (Lanier), no. 30-31, 2015-2016.

Quigley, P., "The Sage of Corwen and White of White," Powys Society Newsletter (London), no. 85, July 2015.

Quigley, P., Sisters Against the Empire: Countess Markievicz and Eva Gore-Booth in 1916-17, Dublin: Liffey Press, 2016.

Robbins, F., Under the Starry Plough: Recollections of the Irish Citizen Army, Dublin: Academy Press, 1977.

White, Captain, “Ireland's Hour,” The Irish Citizen (Dublin), 27.11.1915 \& 4.12.1915.

White, J., Misfit a Revolutionary Life, Dublin: Livewire, 2005 (omits first two chapters of 1930 edition \& includes a postscript and three articles by White on anarchism).

White, J.R., Misfit: An Autobiography, London: Jonathan Cape, 1930 (all quotations used above are from the 1930 edition).

White, J.R., The Significance of Sinn Fein - Psychological, Political and Economic, Dublin: Martin Lester, 1919. 